\section{Cases 13-19}

I have seen seven further cases of battered children with subdural haematomata who have had bilateral subhyaloid haemorrhages. The haemorrhages in these children resolved completely, leaving no sequelae. The children have normal vision.

\section{Comment}

It is not well recognized that permanent visual damage occurs in the battered-baby syndrome. Several of the cases described presented to an ophthalmologist on quite a different occasion, and at a different hospital, to that where they were seen by a paediatrician; thus the paediatrician in charge of the case was not aware that the child suffered any visual disability. Only by chance did I piece together the full history in the first two cases.

The series shows that severe and permanent ocular disease affects a substantial number of battered infants. Though retinal haemorrhages are common in the battered-baby syndrome they are minimal in most cases and undergo complete resolution. It is surprising that external damage to the eyes was not seen in this series, though it has been recorded in battered infants (Cameron et al., 1966). The two cases in which the retina was detached are of special interest in that considerable force is required to cause direct damage to the retina of a child; in one case the social worker suspected that the child had been picked up by the feet and its head repeatedly hit against the door. In nine cases there was a fracture of the skull or subdural haematoma. The associated retinal haemorrhage in four of these cases broke through into the vitreous and subsequently organized, with resultant permanent scarring at the maculae. In three cases cerebral damage led to optic atrophy. Two are in homes for the blind.

The eye that had to be removed showed histological changes similar to those in Coats's disease, and trauma may be the cause of some cases of this puzzling condition (Mushin and Morgan, 1971).

It is therefore evident that the diagnosis of battered-child syndrome must be considered in all cases of severe retinal disease and optic atrophy in childhood; and all infants suspected of being "battered babies" should be referred to an ophthalmologist for complete ocular examination, both at the time of injury and at follow-up.

I would like to thank the staff of Moorfields Eye Hospital and Hammersmith Hospital who have referred cases to me, and in particular Dr. Pamela Davies, Professor Barrie R. Jones, and Professor J. P. M. Tizard for their help in the preparation of this report.

\section{References}

Adelson, L. (1961). New England fournal of Medicine, 264, 1345.

Caffey, J. (1946). American Journal of Roentgenology, Radium Therapy, and Nuclear Medicine, 56, 163.

Cameron, J. M., Johnson, H. R. M., and Camps, F. E. (1966). Medicine, Science and the Law, 6, 2

Gilkes, M. J., and Mann, T. P. (1967). Lancet, 2, 468.

Kempe, L. H., Silverman, F. N., Steele, B. F., Droegemueller, W., and Silver, H. K. (1962). Journal of the American Médical Association, 181,14 .

Kiffney, G. T., jun. (1964). Archives of Ophthalmology, 72, 231.

Maroteaux, P., Fessard, C., and Aron, J. J. (1967). Presse Medicale, 75, 711. Maroteaux, P., and Lamy, M. (1967). Lancet, 2, 829.

Mushin, A. S., and Morgan, G. (1971). British fournal of Ophthalmology, $55,343$.

Silverman, F. N. (1953). American fournal of Roentgenology, Radium Therapy, and Nuclear Medicine, 69, 413.

\title{
Prognosis for Patients with Severe Brain Injuries
}

\author{
MATTI VAPALAHTI, HENRY TROUPP
}

British Medical fournal, 1971, 3, 404-407

\section{Summary}

Intraventricular pressure recording has been a standard procedure in the neurosurgical clinic, University Central Hospital, Helsinki, Finland, since 1964. Up to 31 December 1970, 250 recordings had been performed, 90 of these on brain-injured patients. Intraventricular pressure correlates well with survival or death of the patient but will not predict the quality of survival. However, other criteria seem to correlate well with the quality of survival.

The results of a prospective study of 50 patients between 1 January 1967 and 31 December 1969 are reported. Clues to vegetative survival are very low arterial $\mathbf{P C O}_{2}$ after a free airway has been established, a high respiratory minute volume, temperature above $39^{\circ} \mathrm{C}$, CheyneStokes breathing, and extension rigidity in adults.

Neurosurgical Clinic, Helsinki University Central Hospital, Helsinki, Finland

MATTI VAPALAHTI, L.K.T.

HENRY TROUPP, L.K.T.
When a reliable prognosis can be established that the patient is going to survive only as a vegetative wreck it is highly doubtful if the whole might of modern intensive therapy should be applied.

\section{Introduction}

In spite of all technical advances over the past 20 years many patients still die from brain injury, while some-perhaps the most distressing category among those who survive-will remain purely vegetative beings. We are trying to establish criteria whereby an injury so severe as to lead to merely vegetative survival can be detected at an early stage. Modern methods of care allow such a patient to continue his "posthumous" (Keats, 1948) existence indefinitely, and it is increasingly evident that the difference in outcome (early death, long vegetative survival, or recovery) lies more with the injury than with failure of treatment immediately after the injury. It is out contention that heroic measures are unnecessary if prognosis can be made so certain that injuries leading to early death or vegetative survival can be accurately distinguished from injuries giving a hope of recovery as a social human being.

The death of a patient with brain injury can be predicted days in advance by means of recording the intraventricular pressure (Lundberg et al., 1965; Troupp, 1965, 1967; Johnston et al., 1970; Richardson et al., 1970). A large series has been 
published elsewhere to establish the correlation between intraventricular pressure and the fate of the patient (Vapalahti, 1970). The main results of that series are given in Table I.

TABLE I-Intraventricular Pressure during the First Two Days in 50 Patients with Severe Brain Injury correlated with Final Outcome

\begin{tabular}{|c|c|c|c|c|c|}
\hline \multirow{2}{*}{\multicolumn{2}{|c|}{ Outcome }} & \multicolumn{4}{|c|}{ Pressure (mm Hg) } \\
\hline & & \multirow{2}{*}{$\begin{array}{c}\leqslant 15 \\
6 \\
3 \\
1\end{array}$} & \multirow{2}{*}{$\begin{array}{c}16-30 \\
7 \\
6 \\
2\end{array}$} & \multirow{2}{*}{$\begin{array}{c}31-60 \\
4 \\
3 \\
3\end{array}$} & \multirow{2}{*}{$\begin{array}{r}>60 \\
2 \\
1 \\
12\end{array}$} \\
\hline $\begin{array}{l}\text { Recovered } \\
\text { Vegetative survival } \\
\text { Died } \quad \ldots\end{array}$ & $\begin{array}{l}\cdots \\
\cdots\end{array}$ & & & & \\
\hline & $\ldots$ & 10 & 15 & 10 & 15 \\
\hline
\end{tabular}

"Recovered" means that the patient was a social being again, though possibly requiring institutional care. "Vegetative survival" means that the patient survived for at least one month in our department, that he was followed up for at least a year, if alive then, and that he did not regain consciousness in that time. The two who survived in the group with a pressure above $60 \mathrm{~mm} \mathrm{Hg}$ were both children, one aged 13 years, the other 8 years. Their hyperintensive treatment, with corticosteroids, hyperventilation, dehydrating agents, and ventricular drainage, has been described in detail elsewhere (Vapalahti et al., 1969; Vapalahti, 1970). So far, similar measures applied to adults have always failed.

Though an intraventricular pressure recording can indicate whether survival may be expected it cannot differentiate between patients likely to recover enough to become social human beings again and those likely to remain in a vegetative state and incapable of communication. This prompted us to push further in our search for prognostic criteria.

It is well known that the level of consciousness is intimately related to respiration; when the level of consciousness dropsas, for instance, in normal sleep-there is a definite change in respiration (Bülow, 1963). Consequently we investigated changes in respiratory function as well as some other values in the series of patients mentioned above. (For previous studies of respiratory function in patients with severe brain injuries see Frowein, 1963; Naeraa, 1967; and Froman, 1968).

\section{Patients and Methods}

Intraventricular pressure recording has been a standard procedure in the neurosurgical clinic since 1964. Up to 31 December 1970, 250 recordings had been made, 90 of these on patients with brain injury.

Between 1 January 1967 and 31 December 1969 the 51 patients comprising this series were admitted to the clinic after a severe brain injury, and at the time of admission they were all deeply unconscious, responding only to pain. Forty-one were admitted to the clinic direct or after first aid only, the rest being referred from other hospitals. Thirty-nine patients were admitted within three hours after the accident.

One patient was later found to have an injury of the cervical spinal cord and is not included in further analysis, since the cervical injury affected respiratory function.

All patients admitted direct received acute resuscitative care, which included intubation and cleaning out the airways, combating shock, if any, and emergency splinting of any fractures of large bones. Carotid angiography was carried out and large haematomas were removed; such haematomas were found within 48 hours in 16 patients.

The first respiratory studies were usually made after the acute resuscitative measures, the angiography, and the removal of large haematomas had been carried out. The studies were then repeated on the second day after the injury. For acid-base balance in arterial blood and respiratory minute volume the results of the first and second days were pooled and the mean was calculated for each patient; these means were then used to obtain the results shown in Tables IV and V.

The following measurements were carried out: blood acidbase balance, minute ventilation, respiratory frequency, C.S.F. acid-base balance, physiological dead space, arterial/end-tidal carbon dioxide difference, and arterial/alveolar oxygen difference with the patient breathing $100 \%$ oxygen. In addition the presence or absence of a temperature above $39^{\circ} \mathrm{C}$, CheyneStokes breathing, and extension rigidity were recorded. Hyperthermia was managed by the removal of all clothing, the use of a large fan, and the administration of acetylsalicylate; other drugs were used only in one or two instances.

\section{Results}

Measurements that did not contribute greatly to prognosis (for detailed results see Vapalahti, 1970) were: physiological dead space, arterial/end-tidal carbon dioxide difference, arterial/ alveolar oxygen difference with the patient breathing $100 \%$ oxygen, and respiratory frequency. C.S.F. acid-base balance did not contribute appreciably but some results are reported as they were of high pathological importance.

TABLE II-Hyperthermia and Cheyne-Stokes Breathing in 50 Patients with Severe Brain Injury Correlated with Final Outcome

\begin{tabular}{|c|c|c|c|c|}
\hline \multicolumn{2}{|l|}{ Outcome } & $\begin{array}{l}\text { Temperature } \\
\text { Above } 39^{\circ} \mathrm{C}\end{array}$ & $\begin{array}{c}\text { Cheyne-Stokes } \\
\text { Breathing }\end{array}$ & $\begin{array}{l}\text { Total No. } \\
\text { of Patients }\end{array}$ \\
\hline $\begin{array}{l}\text { Recovered } \\
\text { Vegetative survival } \\
\text { Died } \quad . \quad \ldots\end{array}$ & $\begin{array}{l}\cdots \\
\cdots\end{array}$ & $\begin{array}{l}2 \\
8 \\
4\end{array}$ & $\begin{array}{l}3 \\
7 \\
6\end{array}$ & $\begin{array}{l}19 \\
13 \\
18\end{array}$ \\
\hline Total & .. & 14 & 16 & 50 \\
\hline
\end{tabular}

TABLE III-Extension Rigidity in 50 Patients with Severe Brain Injury correlated with Final Outcome

\begin{tabular}{|c|c|c|c|c|}
\hline Outcome & $\begin{array}{l}\text { Ext. Rigidity, } \\
\text { Whole Series }\end{array}$ & $\begin{array}{l}\text { Total No. } \\
\text { of Patients }\end{array}$ & $\begin{array}{l}\text { Ext. Rigidity, } \\
\text { Adults }\end{array}$ & $\begin{array}{l}\text { Total No } \\
\text { of Adults }\end{array}$ \\
\hline $\begin{array}{l}\text { Recovered ... } \\
\text { Vegetative survival } \\
\text { Died } \quad . .\end{array}$ & $\begin{array}{r}9 \\
11 \\
10\end{array}$ & $\begin{array}{l}19 \\
13 \\
18\end{array}$ & $\begin{array}{r}2 \\
11 \\
8\end{array}$ & $\begin{array}{l}10 \\
13 \\
14\end{array}$ \\
\hline Total & 30 & 50 & 21 & 37 \\
\hline
\end{tabular}

The results for hyperthermia, Cheyne-Stokes breathing, and extension rigidity are given in Tables II and III. Hyperthermia occurred more often among those surviving as vegetative wrecks than among those who recovered $(P<0.01)$. CheyneStokes breathing occurred more often among those who survived as vegetative wrecks than among those who recovered $(P<0.05)$. Extension rigidity is elsewhere also referred to as decerebrate rigidity and brain-stem rigidity, and a variety of other terms are also used. It was seen in 30 patients and proved to be an ominous sign in adults (over 20 years of age) but not in children. Of the two adults who recovered after extension rigidity one had a generalized brain injury and the other had had an extradural haematoma removed.

TABLE IV-Acid-base Balance in Arterial Blood of 50 Patients with Severe Brain Injury correlated with Final Outcome

\begin{tabular}{|c|c|c|c|c|}
\hline Outcome & $\begin{array}{l}\text { No. of } \\
\text { Patients }\end{array}$ & $\mathrm{pH}$ & $\mathrm{PCO}_{2}$ & $\begin{array}{c}\text { Standard } \\
\text { Bicarbonate }\end{array}$ \\
\hline $\begin{array}{l}\text { Recovered } \\
\text { Vegetative survival } \\
\text { Died .. } \quad . .\end{array}$ & $\begin{array}{l}19 \\
13 \\
18\end{array}$ & $\begin{array}{l}7 \cdot 413 \\
7 \cdot 465 \\
7 \cdot 414\end{array}$ & $\begin{array}{l}35 \cdot 9 \\
31 \cdot 1 \\
34 \cdot 6\end{array}$ & $\begin{array}{l}22 \cdot 9 \\
24 \cdot 3 \\
21 \cdot 9\end{array}$ \\
\hline
\end{tabular}


Data on arterial acid-base balance are given in Table IV and Fig. 1. For $\mathrm{pH}$ there was a difference between those surviving as vegetative wrecks and those who recovered $(P<0.001)$ and between those surviving as vegetative wrecks and those who died $(P<0.01)$. For $\mathrm{PCO}_{2}$ there was a difference between those who recovered and those who survived as vegetative wrecks $(\mathrm{P}<0 \cdot 05)$. The $\mathrm{PcO}_{2}$ values during the first four days are shown in Fig. 1. It should be noted that out of 11 patients with $\mathrm{PCO}_{2}$ values below $25 \mathrm{~mm} \mathrm{Hg}$ at some time during the first two days-all of whom were breathing spontaneouslythree died and eight remained vegetative wrecks.

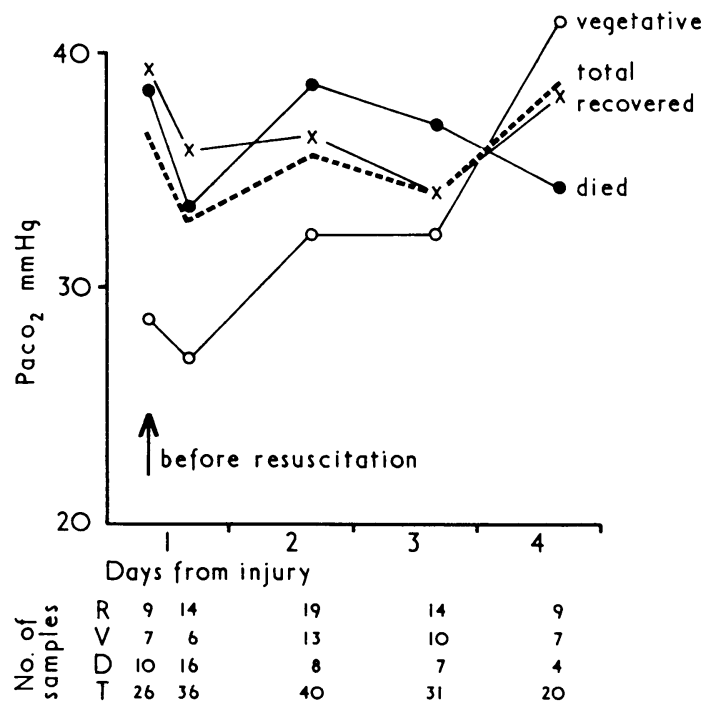

FIG. 1-Arterial carbon dioxide tension in patients with severe brain injury correlated with final outcome. $\mathbf{R}=$ Recovered. $\mathrm{V}=$ Vegetative survival. $\mathrm{D}=$ Dead. $\mathrm{T}=$ Total series. Thick broken line indicates mean for total series shown in figure. There was a difference between $R$ and $V$ values before resuscitation $(P<0.05)$ and on the first day $\left(P<0^{\circ} 01\right)$.

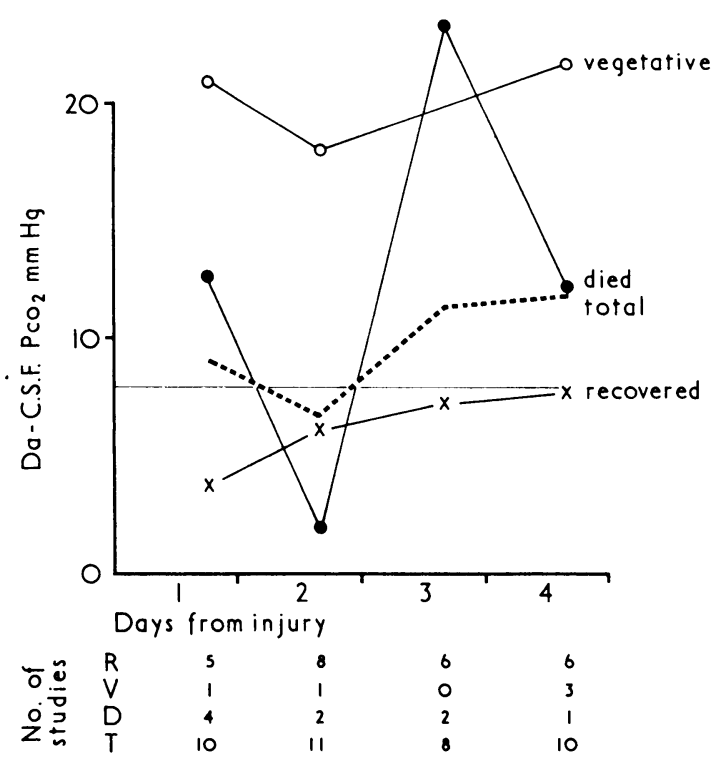

FIG. 2-Difference between arterial and C.S.F. carbon dioxide tension correlated with final outcome in patients with severe brain injury. $R=$ Recovered. $\mathrm{V}=$ Vegetative survival. $\mathrm{D}=$ Dead. $\mathrm{T}=$ Total series. Thick broken line indicates mean for total series shown in figure. The trends are not statistically significant.
TABLE V-Respiratory Minute Volume in 28 Adult Patients with Severe Brain Injury correlated with Final Outcome

\begin{tabular}{|c|c|c|c|}
\hline Outcome & & $\begin{array}{c}\text { Respiratory Volume } \\
(1 . / \mathrm{min})\end{array}$ & $\begin{array}{l}\text { No. of Patients } \\
\text { Investigated }\end{array}$ \\
\hline $\begin{array}{l}\text { Recovered ... } \\
\text { Vegetative survival } \\
\text { Died }\end{array}$ & $\begin{array}{l}\cdots \\
\cdots\end{array}$ & $\begin{array}{l}11 \cdot 7 \\
16 \cdot 2 \\
10 \cdot 3\end{array}$ & $\begin{array}{r}9 \\
8 \\
11\end{array}$ \\
\hline
\end{tabular}

Data on respiratory minute volume are given in Table V. Only adult patients were included for these results, as we had no means of weighing the patients in bed. A difference was noted between those who survived as vegetative wrecks and those who recovered $(P<0.05)$ and between those who survived as vegetative wrecks and those who died $(P<0.01)$.

C.S.F. acid-base balance offers interesting features for further research. The data for the difference in carbon dioxide tension between arterial blood and ventricular C.S.F. over the first four days are given in Fig.. 2. In spite of the considerable apparent differences they have no statistical significance, as these studies were performed on so few patients.

\section{Discussion}

Before the inception of this study we used respiratory arrest, excessive slowing or stoppage of the cerebral circulation (Heiskanen, 1964), the age of the patient (Carlsson et al., 1968; Heiskanen and Sipponen, 1970), and intraventricular pressure (Troupp, 1965, 1967) as prognostic guides. These data, however, could give us a reliable guide only to survival $v$. death, and not to the quality of survival, which is almost as important as survival itself-at least, in the case of patients with severe brain injuries. There can be few sights more depressing than a vegetative wreck, a burden both to his family and to the institution that ultimately has to care for him. Such an existence can be described as neither human nor humane.

We think that we have now defined certain prognostic criteria which distinguish between acceptable survival and vegetative survival. Thus with present data it would seem futile to attempt intensive therapy for a brain injury in a patient over 20 years of age who was Cheyne-Stokes breathing, hyperthermia above $39^{\circ} \mathrm{C}$, severe respiratory alkalosis, and extension rigidity-provided, of course, that these are due to the brain injury and not to concomitant injuries or inadequate first aid. One can, of course, speculate about the reasons for the correlation of these findings with the fate of the patient; perhaps these violent reactions denote a brain injury so severe as to preclude recovery. It has been shown experimentally that the animals hyperventilating most after a standardized cold injury of the brain survive the longest (Kaste, 1970); the same may apply to man, but the experimental injury referred to was designed to be lethal, and the quality of survival did not enter into it.

For children, on the other hand, the hyperintensive therapy outlined above-extreme hyperventilation, corticosteroids, dehydrating agents, and ventricular drainage as a last resortdoes seem to be worth while. Thus except for children our present routine methods-that is, intubation, tracheostomy, combating of shock, adequate fluid therapy, prompt diagnosis, and removal of large haematomas-would seem to be sufficient to sort out the survivors from those whom no further measures can reclaim from death. Our suggested criteria could indicate whether acceptable recovery can be expected or merely vegetative survival.

\section{References}

Bülow, K. (1963). Acta Physiologica Scandinavica, 59, Suppl. No. 209. Carlsson, C.-A., von Essen, C., and Löfgren, J. (1968). Ұournal of Neurosurgery, 29, 242. 
Froman, C. (1968). British Fournal of Anaesthesia, 40, 354.

Frowein, R. A. (1963). Zentralc Atemstörungen bei Schädel-Hirn-Verletzungen und bei Hirntumoren. Berlin, Springer.

Heiskanen, O. (1964). Acta Neurologica Scandinavica, 40, Suppl. No. 7 Heiskanen, O., and Sipponen, P. (1970). Acta Neurologica Scandinavica, $46,343$.

Johnston, I. H., Johnston, J. A., and Jennett, W. B. (1970). Lancet, 2, 433.

Kaste, M. (1970). Experimental brain injury. Its effects on cerebral sinus pressure, cerebral venous oxygen tension, respiration, blood pressure and acid-base balance. University of Helsinki.

Keats, J. (1948). In The Letters of Fohn Keats, ed. M. Buxton Forman, p. 526. Oxford, Oxford University Press.
Lundberg, N., Troupp, H., and Lorin, H. (1965). Fournal of Neurosurgery, 22,581 .

Naeraa, N. (1967). Aendringer i lungefunktion og syre-base status hos bevidstlose neurokirurgiske patienter. University of Arhus.

Richardson, A., Hide, T. A. H., and Eversden, I. D. (1970). Lancet, 2, 687. Richardson, A., Hide, T. A. H., and Eversden,
Troupp, H. (1965). Fournal of Trauma, 5,373 .

Troupp, H. (1965). Fournal of Trauma, 5, 373.

Vapalahti, M. (1970). Intracranial pressure, acid-base status of blood and cerebrospinal fluid, and pulmonary function in the prognosis of severe brain injury. University of Helsinki.

Vapalahti, M., Troupp, H., and Heiskanen, O. (1969). In Cerebral Blood Flow', ed.' M. Brock, C. Fieschi, D. H. Ingvar, N. A. Lassen, and K. Schürmann, p. 266. Berlin, Springer.

\section{Nitroprusside Revisited}

\section{K. MANI}

British Medical fournal, 1971, 3, 407-408

\section{Summary}

Sodium nitroprusside is a readily available, powerful hypotensive agent. It was administered intravenously in four cases when all other available hypotensive agents had failed, and blood pressure was controlled promptly and with no side effects. This is a valuable drug and deserves wider use.

\section{Introduction}

The value of sodium nitroprusside in the treatment of hypertensive emergencies is well established. However, it has been little used because it is thought to be too toxic. In my experience of the drug, limited to four patients, I found it effective and safe.

\section{Methods}

A solution of sodium nitroprusside containing $50 \mathrm{mg}$ of the drug in a litre of $5^{\circ}{ }_{0}^{\prime}$ dextrose solution was made up according to the method described by Gifford (1970). This was administered as an intravenous drip. Blood pressure was recorded continuously during the first 10 minutes by a standard sphygmomanometer, the cuff being deflated fully after each reading, and thereafter every 10 minutes while the infusion was maintained. The quantities of sodium nitroprusside used in each case and the period for which they were infused are given in Table $\mathrm{I}$.

TABLE I-Amount of Sodium Nitroprusside Infused in Four Cases and Period over which it was Administered

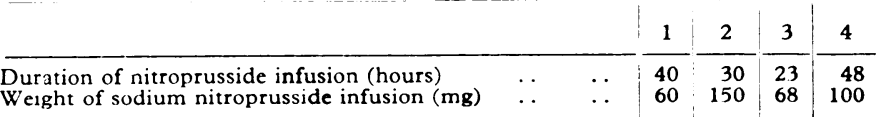

\section{Case Report}

Case 1.-A 37-year-old man had a two-year history of hypertension. Six weeks before he entered hospital his blood pressure

\section{Sydney Hospital, Sydney, Australia}

M. K. MANI, M.D., Physician to Renal, Dialysis, and Transplant Units (Present address: Stanley Medical College, Madras, India) began to rise despite continuing treatment and his renal function began to deteriorate. On admission he had a blood pressure of $210 / 150 \mathrm{~mm} \mathrm{Hg}$, a grade IV hypertensive retinopathy, pulmonary oedema, and a serum creatinine level of $16.3 \mathrm{mg} / 100 \mathrm{ml}$. Treatment with clonidine $900 \mathrm{mg}$, debrisoquine $40 \mathrm{mg}$, and ethacrynic acid 200 $\mathrm{mg}$ daily, together with reserpine $12 \mathrm{mg}$ intramuscularly daily for the first two days and pentolinium $50 \mathrm{mg}$ subcutaneously daily for the next two days, had no effect on the blood pressure. Diazoxide $600 \mathrm{mg}$ intravenously on the fifth day was also ineffectual. Peritoneal dialy' is was instituted to try to control azotaemia before bilateral nephrectomy (Stokes et al., 1970) and to attempt to lower the blood pressure by dehydration. He lost $10 \mathrm{~kg}$ in weight after 24 hours of dialysis, but his blood pressure rose to $270 / 170 \mathrm{~mm} \mathrm{Hg}$. An infusion of sodium nitroprusside then controlled the blood pressure satisfactorily (Table II). Bilateral nephrectomy was carried out, blood pressure returned to normal, and no further medication was required. The patient received a renal allograft a year later.

Case 2.-A 54-year-old man had a two-year history of hypertension for which he was receiving treatment. On admission he was drowsy and disorientated. The blood pressure was $240 / 170 \mathrm{~mm}$ $\mathrm{Hg}$, there was an early diastolic murmur over the aortic and left parasternal area, grade IV hypertensive retinopathy was present, and the serum creatinine level was $15.3 \mathrm{mg} / 100 \mathrm{ml}$. An infusion of sodium nitroprusside rapidly lowered the blood pressure (Table II), but the serum creatinine level remained high and the cerebral state did not improve. Peritoneal dialysis was instituted, but he died eight hours later.

TABLE II-Blood pressure control with sodium nitroprusside and other antihypertensive agents. The figures are the means of all the systolit: and diastolic readings taken in the lying position during the patients' stay in Hospital before readings taken in the lying position during the patients' stay in Hospital before
and during the infusion of sodium nitroprusside. Standard deviation of each set and during the infusion of sodium nitro
of readings is given in parentheses

\begin{tabular}{|c|c|c|c|c|c|}
\hline & \multirow[t]{2}{*}{ Case No. } & \multicolumn{2}{|c|}{$\begin{array}{l}\text { B.P. in } \mathrm{mm} \mathrm{Hg} \text { on Other } \\
\text { Antihypertensive Agents }\end{array}$} & \multicolumn{2}{|c|}{$\begin{array}{l}\text { B.P. in } \mathrm{mm} \mathrm{Hg} \text { during } \\
\text { Administration of } \\
\text { Nitroprusside }\end{array}$} \\
\hline & & Mean (S.D.) & Range & Mean (S.D.) & Range \\
\hline 1 & . & $\frac{220(29)}{140(11)}$ & $\frac{160-270}{120-170}$ & $\frac{157(20)}{105(13)}$ & $\frac{90-180}{80-130}$ \\
\hline 2 & & $\frac{237(8)}{163(6)}$ & $\frac{220-240}{160-170}$ & $\frac{160(9)}{100(8)}$ & $\frac{150-170}{90-110}$ \\
\hline 3 & . & $\frac{169(28)}{127(21)}$ & $\frac{100-220}{60-170}$ & $\frac{146(19)}{97(13)}$ & $\frac{100-200}{60-130}$ \\
\hline $4^{*}$ & . & $\frac{168(37)}{120(27)}$ & $\frac{90-230}{70-170}$ & $\frac{130(17)}{96(7)}$ & $\frac{100-150}{80-105}$ \\
\hline
\end{tabular}

*The readings while the patient was on peritoneal dialysis have been omitted (see text).

Case 3.-A 29-year-old man had had no symptoms until five days before admission when he developed blurring of vision, and on the morning of admission frank haematuria developed. His 